\title{
Keunikan Dalam Mempelajari SROI
}

\section{Nama : Rizki Akbar}

\section{Email : s130118061@student.ubaya.ac.id}

SROI ialah suatu pendekatan yang relatif baru untuk menilai dan menginformasikan keputusan alokasi sumber daya, akuntansi keuangan secara umum di sektor swasta maupun publik yang diciptakan oleh manusia ( Nicholls, 2017 ). Salah satu contoh yang dapat diambil, yaitu Surabaya Green and Clean Festival yang telah mendorong komunitas lokal di kota Surabaya serta dapat mengembangkan lingkungan disekitarnya. Dari event tersebut yang telah dilakukan yaitu, mampu mengelola sampah secara rutin dengan cara diadvokasi dalam strategi nasional untuk kebijakan desentralisasi ( Bunnell, Miller, Phelps, \& Taylor, 2013 ). Beberapa artikel yang juga menggunakan pendekatan SROI:

SROI diterapkan untuk menyelidiki fenomena yang masih sedikit dieksplorasi oleh masyarakat ( Ricciuti \& Bufali, 2019 ). Deskripsi awal dari metodologi untuk menghitung SROI menunjukkan bahwa pendekatan awalnya berevolusi dari metodologi standar yang ditemukan dalam literatur keuangan bisnis untuk mengevaluasi investasi, dengan perubahan penting bahwa pengembalian sektor nirlaba didefinisikan dalam istilah sosial yang lebih luas ( Thornley, Anderson, \& Dixon, 2016 ). Menurut ( Winrow \& Edwards, 2018 ), dalam penggunaan SROI berguna untuk mengukur berbagai nilai di pemangku kepentingan untuk mengidentifikasi manfaat atau kerugian yang memiliki dampak sosial, ekonomi, ataupun lingkungan. Pengenbalian Investasi Sosial ( SROI ), sebuah kerangka kerja yang diakui oleh pemerintah, mengeksplorasi nilai sosial yang lebih luas dari intervensi, tetapi belum sejauh pengetahuan kami digunakan untuk mengukur nilai prosedur pembedahan ( Baker, Courtney, \& Knepil, 2019 ). Menurut ( Bosco, Schneider, \& Broome, 2019 ), kami menggunakan analisis laba atas investasi sosial ( SROI ) untuk menilai manfaat sosial dan ekonomi dari intervensi seni. 


\section{Reference}

Pratono, A.H., Suyanto, D Marciano, Zurbrügg, C. (2017) The Hong Kong Journal of Social Work 51 (01n02), 93-114

Bosco A, Schneider J, Broome E ( 2019 ) The social value of the arts for care home residents in England: A Social Return on Investment ( SROI ) analysis of the Imagine Arts programme, Maturitas ( 124 ), 15-24

Ricciuti E, Bufali M.V ( 2019 ) The heath and social impact of Blood Donors Association: A Social Return on Investment analysis, Evaluation and Program Planning ( 73 ), 204-213

Winrow E, Prof. Edwards R.T, ( 2018 ) Effectiveness and stakeholder impact of the Sistema Cymru - Codi'r To music programme in north Wales: a social return on investment evaluation, The Lancet 392(2), S93

Baker C, Courtney P, Knepil G ( 2019 ) Social Return on Investment methodology applied to patients followimg orthognathic surgery, British Journal of Oral and Maxillofacial Surgery 55(10), e170-e171 